\title{
Management of anticoagulant therapy during pregnancy in patients with prosthetic heart valves
}

\author{
B. STEPHEN JENKINS and MARK V. BRAIMBRIDGE \\ Department of Cardiothoracic Surgery, St. Thomas' Hospital, London S.E.1
}

\begin{abstract}
We describe two patients with Starr-Edwards mitral valve replacements who underwent pregnancy on oral anticoagulants and who were successfully delivered of live babies. The literature on pregnancy with prosthetic heart valves is reviewed. It is suggested that properly controlled oral anticoagulation should be continued until the onset of labour; the anticoagulant effect should then be reversed by an intravenous infusion of fresh-frozen plasma and the patient maintained on intravenous heparin injections six-hourly. Oral anticoagulants should be restarted immediately after delivery and the heparin withdrawn only when their effect has been re-established.
\end{abstract}

The continuing improvement in mortality after prosthetic valve replacement and the wider selection of younger patients for such procedures imply that increased numbers of women of childbearing age will undergo such operations and will subsequently become pregnant.

At present virtually all patients with ball valve or similar prostheses have anticoagulant therapy. The inherent difficulties of managing a pregnancy complicated by heart disease are thus considerably increased. It is generally accepted that anticoagulant therapy is best avoided during pregnancy. Bennett and Oakley (1968) reported the death of a mother with a mitral valve prosthesis and her infant, leading to the assertion that pregnancy must be avoided on the grounds that anticoagulant therapy is dangerous to mother and fetus and that the pregnancy itself may increase the likelihood of thromboembolism. Sterilization of patients with such prostheses was advised. Several subsequent reports (Johnson et al., 1966 ; Starke, Dunn, and Kittle, 1967 ; Strickland and Mount, 1966; Turner and Kitchin, 1968 ; Gordon and Dean, 1955; Harthorne, Buckley, Grover, and Austen, 1967; Ueland, Tatum, and Metcalfe, 1966 ; Hedstrand and Cullhed, 1968 ; Bloomfield and Rubinstein, 1969 ; Zitnik, Brandenburg, Sheldon, and Wallace, 1969) were more optimistic but a few (DiSaia, 1966; Kerber, Warr, and Richardson, 1968 ; Kenmure, 1968, and Otterson, McGranahan, and Freeman, 1968), and, in particular, a recent report by Palacios-Macedo, DíazDevis, and Escudero (1969) of five fetal deaths, suggest that a review of the problem is desirable.

To date there are reports of 26 pregnancies in patients with prosthetic heart valves, 15 involving the mitral valve (Table I), 10 the aortic valve (Table II), and in one patient both aortic and mitral valves. One patient received a McGovern aortic prosthesis (Otterson et al., 1968) and one a Hammersmith mitral valve (Bennett and Oakley, 1968), the remainder having Starr-Edwards valves.

We report two further successful pregnancies in patients with Starr-Edwards mitral valve prostheses and review the previously published cases. We attempt to assess the risk of pregnancy in these patients and suggest how their anticoagulant therapy should be managed.

\section{CASE REPORTS}

CASE $1^{1}$ An Irish housewife had an uneventful first $N$ pregnancy at the age of 20 years and a second pregnancy two years later. Following a third pregnancy at the age of 26 she had a severe episode of rheumatic $\mathrm{\omega}$ fever but five years later a fourth child was born after $\underset{<}{\sigma}$ a normal pregnancy. Subsequently she developed congestive cardiac failure due to severe mitral valve $\frac{\bar{D}}{\overparen{ }}$ disease, predominantly mitral incompetence, compli- $\stackrel{\infty}{+}$ cated by atrial fibrillation. A silastic ball Starr- $\square$ Edwards mitral valve was inserted when she was aged $\overline{0}$ 33 years. Long-term warfarin was started on the fifth postoperative day. On return to Ireland her only addi- $\frac{\rho}{\square}$ tional medication was digoxin. Eight months later she $\stackrel{\mathbb{Q}}{\Omega}$ became pregnant and after an entirely normal preg-

1Briefly reported by Carty and Crowdes (1968) 
nancy was delivered of a healthy child. The warfarin was continued throughout pregnancy until six days before the estimated day of delivery; at this stage heparin, 10,000 iu, was given intramuscularly twice daily. Immediately following delivery warfarin was restarted and the heparin was subsequently stopped. She remains well on digoxin and warfarin only.

CASE 2 An English housewife developed congestive cardiac failure during her first pregnancy at the age of 24 years. Despite full medical treatment episodes of heart failure recurred due to severe mitral incompetence with moderate tricuspid and trivial aortic valve disease, complicated by atrial fibrillation. At the age of 30 a silastic ball Starr-Edwards mitral valve was inserted and long-term phenindione was started on the fifth postoperative day. Following operation her effort tolerance markedly improved. Six months later direct current cardioversion successfully restored sinus rhythm but atrial fibrillation recurred after two weeks. Pregnancy was thought initially to be unwise but a year later her progress was such that this advice was altered and 16 months after surgery she became pregnant. Full anticoagulation was maintained with phenindione until the 37th week when warfarin was substituted (because this is the oral anticoagulant now used almost exclusively in this hospital and the wider experience with this drug was thought desirable for critical anticoagulant control during the last three weeks of pregnancy). At no time during pregnancy did the prothrombin ratio fall below 1.4 or exceed 2.5 . Of the 28 estimations of prothrombin ratio made during pregnancy $26(93 \%)$ showed full anticoagulation. With the onset of labour, $300 \mathrm{ml}$ fresh-frozen plasma and 10,000 iu heparin were given intravenously, followed by a further $300 \mathrm{ml}$ fresh-frozen plasma. Heparin in the same dosage was continued six-hourly by the intravenous route. After 18 hours it was decided to perform a Caesarean section for uterine inertia and the heparin was stopped. The operation was performed successfully and a normal child was delivered. Warfarin, $30 \mathrm{mg}$ orally, was given immediately after

T A BLE I

MITRAL VALVE REPLACEMENT

\begin{tabular}{|c|c|c|c|c|c|c|c|c|}
\hline \multirow[b]{2}{*}{ Author } & \multirow[b]{2}{*}{ Valve } & \multirow{2}{*}{$\begin{array}{c}\text { Time } \\
\text { between } \\
\text { Operation } \\
\text { and } \\
\text { Pregnancy } \\
\text { approx. }\end{array}$} & \multirow{2}{*}{$\begin{array}{l}\text { Systemic } \\
\text { Emboli } \\
\text { before } \\
\text { Pregnancy }\end{array}$} & \multicolumn{2}{|c|}{ Anticoagulant Therapy } & \multirow{2}{*}{$\begin{array}{l}\text { Systemic } \\
\text { Emboli in } \\
\text { Pregnancy }\end{array}$} & \multicolumn{2}{|c|}{ Complications } \\
\hline & & & & $\begin{array}{c}\text { Before } \\
\text { Pregnancy }\end{array}$ & $\begin{array}{c}\text { During } \\
\text { Pregnancy }\end{array}$ & & Fetal & Maternal \\
\hline $\begin{array}{l}\text { Bennett and } \\
\text { Oakley (1968) }\end{array}$ & $\mathbf{H}$ & $2 \frac{1}{2} y r$ & None & Warfarin & $\begin{array}{l}\text { Heparin s.c. to } 28 / 52 \\
\text { Heparin i.v. to delivery }\end{array}$ & $\begin{array}{c}\text { At } 8 / 52 \\
\text { and } 19 / 52\end{array}$ & Died at $9 \mathrm{hr}$ & $\begin{array}{l}\text { Died; cardiac } \\
\text { and renal } \\
\text { failure }\end{array}$ \\
\hline DiSaia (1966) & $\mathbf{S}-\mathbf{E}$ & $4 \mathrm{mth}$ & None & Warfarin & $\begin{array}{l}\text { Warfarin stopped at labour } \\
\text { Heparin during labour }\end{array}$ & None & $\begin{array}{l}\text { Mental abnor- } \\
\text { mality; blind; } \\
\text { saddle nose }\end{array}$ & $\begin{array}{l}\text { Haematoma at } \\
\text { episiotomy site } \\
\text { on } 4 \text { th day; } \\
\text { ?lues }\end{array}$ \\
\hline $\begin{array}{l}\text { Johnson et al. } \\
\text { (1966) }\end{array}$ & $\begin{array}{l}\text { S-E } \\
\text { S-E }\end{array}$ & $\begin{array}{l}7 \mathrm{mth} \\
8 \mathrm{mth}\end{array}$ & $\begin{array}{l}\text { None } \\
\text { None }\end{array}$ & $\begin{array}{l}\text { Warfarin } \\
\text { Warfarin }\end{array}$ & $\begin{array}{l}\text { Warfarin stopped } 4 / 52 \\
\text { before delivery } \\
\text { Warfarin stopped } 4 / 52 \\
\text { before delivery }\end{array}$ & $\begin{array}{l}\text { None } \\
\text { None }\end{array}$ & $\begin{array}{l}\text { None } \\
\text { None }\end{array}$ & $\begin{array}{l}\text { None } \\
\text { None }\end{array}$ \\
\hline $\begin{array}{l}\text { Turner and } \\
\text { Kitchin (1968) } \\
\text { Bloomfield and } \\
\text { Rubenstein } \\
\text { (1969) }\end{array}$ & $\begin{array}{l}\text { S-E } \\
\text { S-E }\end{array}$ & $\begin{array}{l}1 \mathrm{yr} \\
9 \mathrm{mth} \\
5 \mathrm{yr}\end{array}$ & $\begin{array}{l}\text { None } \\
\text { None }\end{array}$ & $\begin{array}{l}\text { Warfarin } \\
\text { Warfarin }\end{array}$ & $\begin{array}{l}\text { Warfarin stopped at onset } \\
\text { of labour } \\
\text { Warfarin stopped at } 36 / 52 \\
\text { Heparin s.c. till labour }\end{array}$ & $\begin{array}{l}\text { None } \\
\text { None }\end{array}$ & $\begin{array}{l}\text { None } \\
\text { None }\end{array}$ & $\begin{array}{c}\text { None } \\
\text { Vaginal } \\
\text { haematoma }\end{array}$ \\
\hline $\begin{array}{l}\text { Kerber et al. } \\
\text { (1968) }\end{array}$ & $\mathbf{S}-\mathbf{E}$ & $1 \mathrm{yr}$ & $\begin{array}{l}\text { Cerebral } \\
\text { immediately } \\
\text { post-op. }\end{array}$ & Warfarin & $\begin{array}{l}\text { Warfarin stopped } 31 / 52 \\
\text { Heparin s.c. till } 2 / 7 \text { before } \\
\text { delivery }\end{array}$ & None & $\begin{array}{l}\text { Hypoplastic } \\
\text { nasal bones; } \\
\text { fits; slow }\end{array}$ & None \\
\hline $\begin{array}{l}\text { Harthorne et al. } \\
\text { (1967) }\end{array}$ & $\mathbf{S}-\mathbf{E}$ & $\begin{array}{l}4 / 52 \\
\text { pregnant }\end{array}$ & None & 一 & $\begin{array}{l}\text { Warfarin till } 28 / 52 \\
\text { Heparin till labour }\end{array}$ & None & $\begin{array}{l}\text { development } \\
\text { None }\end{array}$ & None \\
\hline $\begin{array}{l}\text { Kenmure } \\
\text { (1968) }\end{array}$ & $\mathbf{S}-\mathbf{E}$ & 4 mth & $\begin{array}{l}\text { Immediately } \\
\text { post-op. and } \\
\text { 3/12 later }\end{array}$ & Warfarin & $\begin{array}{l}\text { Warfarin till premature } \\
\text { labour at } 33 / 52\end{array}$ & None & $\underset{33 / 52}{\text { Stillborn at }}$ & Diabetes \\
\hline $\begin{array}{l}\text { Gordon and } \\
\text { O'Loughlin } \\
\text { (1969) }\end{array}$ & $\mathbf{S}-\mathbf{E}$ & $6 \mathrm{yr}$ & $\begin{array}{l}2 \text { yr post-op. } \\
\text { after anti- } \\
\text { coagulants } \\
\text { stopped }\end{array}$ & Phenindione & $\begin{array}{l}\text { Phenindione until onset of } \\
\text { labour }\end{array}$ & None & None & None \\
\hline $\begin{array}{l}\text { Palacios- } \\
\text { Macedo } \\
\text { et al. } \\
\text { (1969) } \\
\text { Present }\end{array}$ & $\begin{array}{l}\mathbf{S}-\mathbf{E} \\
\mathbf{S}-\mathbf{E} \\
\mathbf{S}-\mathbf{E}^{\mathbf{1}} \\
\mathbf{S}-\mathbf{E} \\
\mathbf{S}-\mathbf{E} \\
\mathbf{S}-\mathbf{E} \\
\mathbf{S}-\mathbf{E}\end{array}$ & $\begin{array}{l}2-19 \\
\text { mth } \\
8 \mathrm{mth}\end{array}$ & $\begin{array}{l}\text { None } \\
\text { None } \\
\text { None } \\
\text { None } \\
\text { None } \\
\text { None } \\
\text { None }\end{array}$ & $\begin{array}{l}\text { None } \\
\text { Acenocumarin } \\
\text { Acenocumarin } \\
\text { Acenocumarin } \\
\text { Acenocumarin } \\
\text { Acenocumarin } \\
\text { Warfarin }\end{array}$ & $\begin{array}{l}\text { None } \\
\text { Acenocumarin till labour } \\
\text { Acenocumarin till labour } \\
\text { Acenocumarin till labour } \\
\text { Acenocumarin till labour } \\
\text { Acenocumarin till labour } \\
\text { Warfarin till } 39 / 52 \\
\text { Heparin through labour }\end{array}$ & $\begin{array}{l}\text { None } \\
\text { None } \\
\text { None } \\
\text { None } \\
\text { None } \\
\text { None } \\
\text { None }\end{array}$ & $\begin{array}{l}\text { None } \\
\text { Stillborn } \\
\text { Stillborn } \\
\text { Infant died } \\
\text { Infant died } \\
\text { Stillborn } \\
\text { None }\end{array}$ & $\begin{array}{l}\text { None } \\
\text { None } \\
\text { None } \\
\text { None } \\
\text { None } \\
\text { None } \\
\text { None }\end{array}$ \\
\hline cases & $\mathbf{S}-\mathbf{E}$ & $\begin{array}{l}1 \mathrm{yr} \\
4 \mathrm{mth}\end{array}$ & None & Phenindione & $\begin{array}{l}\text { Phenindione till } 36 / 52 \\
\text { Warfarin till labour }\end{array}$ & None & None & $\begin{array}{l}\text { Haematoma in } \\
\text { L.S.C.S. } \\
\text { wound }\end{array}$ \\
\hline
\end{tabular}


T A B L E I I

AORTIC VALVE REPLACEMENT

\begin{tabular}{|c|c|c|c|c|c|c|c|c|}
\hline \multirow{3}{*}{ Author } & \multirow{3}{*}{ Valve } & \multirow{3}{*}{$\begin{array}{c}\text { Time } \\
\text { between } \\
\text { Operation } \\
\text { and } \\
\text { Pregnancy } \\
\text { approx. }\end{array}$} & \multirow{3}{*}{$\begin{array}{l}\text { Systemic } \\
\text { Emboli } \\
\text { before } \\
\text { Pregnancy }\end{array}$} & \multicolumn{2}{|c|}{ Anticoagulant Therapy } & \multirow{3}{*}{$\begin{array}{l}\text { Systemic } \\
\text { Emboli in } \\
\text { Pregnancy }\end{array}$} & \multirow{2}{*}{\multicolumn{2}{|c|}{ Complications }} \\
\hline & & & & Before & During & & & \\
\hline & & & & Pregnancy & Pregnancy & & Fetal & Maternal \\
\hline \multirow{6}{*}{$\begin{array}{l}\text { Starke et al. } \\
\text { (1967) } \\
\text { Strickland and } \\
\text { Mount (1966) } \\
\text { Ueland et al. } \\
\text { (1966) } \\
\text { Hedstrand and } \\
\text { Cullhed (1968) }\end{array}$} & S-E & $11 \mathrm{mth}$ & None & None & None & None & None & None \\
\hline & S-E & 6 wk & Cerebral & & None & None & None & None \\
\hline & S-E & $3 \mathrm{mth}$ & $\begin{array}{l}\text { post-op. } \\
\text { None }\end{array}$ & Warfarin & Stopped when pregnancy & None & None & None \\
\hline & $\begin{array}{l}\text { S-E } \\
\text { S-E }\end{array}$ & $\begin{array}{l}6 \mathrm{wk} \\
2 \mathrm{yr}\end{array}$ & $\begin{array}{l}\text { None } \\
\text { None }\end{array}$ & $\begin{array}{c}\text { None } \\
\text { Dicoumarol }\end{array}$ & $\begin{array}{l}\text { None } \\
\text { Dicoumarol reduced } 30 / 52\end{array}$ & $\begin{array}{l}\text { None } \\
\text { None }\end{array}$ & $\begin{array}{l}\text { None } \\
\text { None }\end{array}$ & $\begin{array}{l}\text { None } \\
\text { None }\end{array}$ \\
\hline & $\mathbf{S}-\mathbf{E}$ & $2 \mathrm{yr}$ & None & Dicoumarol & $\begin{array}{l}\text { Dicoumarol stopped } 33 / 52 \\
\text { restarted 35/52. } \\
\text { substituted } 1 / 52 \text { Heparin } \\
\text { labour }\end{array}$ & $\begin{array}{l}\text { Cerebral } \\
\text { and renal } \\
35 / 52\end{array}$ & None & None \\
\hline & S-E & & $\begin{array}{l}\text { Cerebral } \\
\text { post-op. }\end{array}$ & Dicoumarol & $\begin{array}{l}\text { Dicoumarol stopped } 36 / 52 \\
\text { Heparin till term }\end{array}$ & None & & None \\
\hline \multirow{3}{*}{$\begin{array}{l}\text { Zitnik et al. } \\
\text { (1969) } \\
\text { Gordon and } \\
\text { O'Loughlin } \\
\text { (1969) } \\
\text { Otterson et al. } \\
\text { (1968) }\end{array}$} & S-E & $\begin{array}{l}3 / 52 \text { preg- } \\
\text { nant at op. }\end{array}$ & & & ? & None & None & None \\
\hline & S-E & $11 \mathrm{mth}$ & None & Phenindione & $\begin{array}{l}\text { Phenindione stopped at } \\
\text { onset of labour }\end{array}$ & None & None & None \\
\hline & $\mathbf{M}$ & $2 \mathrm{yr}$ & None & Warfarin & $\begin{array}{l}\text { Warfarin till } 12 / 52 \\
\text { Heparin till term }\end{array}$ & At $14 / 52$ & None & None \\
\hline
\end{tabular}

S-E $=$ Starr-Edwards.

$\mathbf{M}=\mathbf{M c G o v e r n}$.

operation and heparin was continued for 36 hours post-delivery. A haematoma developed in the wound on the fifth postoperative day when the prothrombin ratio was 1.4. Bleeding was controlled by the local instillation of thrombin. Mother and child made an uneventful recovery and both are now well.

\section{REVIEW OF REPORTED CASES}

Details concerning the 26 previously reported cases and the two cases now reported are given in Tables I and II which refer to patients with mitral or aortic valve replacements respectively. The one patient with aortic and mitral valve replacement is included in Table $I$.

MITRAL VALVE REPLACEMENT Eighteen patients had mitral valve replacements.

Maternal complications One patient (Bennett and Oakley, 1968) died shortly after delivery and she was the only one in this group who suffered systemic emboli during pregnancy. The emboli occurred while the patient was receiving heparin subcutaneously. Post-mortem examination showed clot around the valve prosthesis, which was of the Hammersmith type. There were no other maternal deaths. Three patients (Gordon and O'Loughlin, 1969 ; Kerber et al., 1968 ; Kenmure, 1968) suffered systemic emboli in the interval between cardiac surgery and pregnancy but none of these had emboli during pregnancy.
Fetal complications Only nine patients in this group produced healthy infants. Two infants had mental abnormalities and deformity of the nasal bones. Of the remaining seven, four were stillborn and three died shortly after delivery.

Anticoagulants Sixteen patients were on? coumarin or indanedione anticoagulants at con-ception and during the first trimester. In the case reported by Harthorne et al. (1967) the valve re-을 placement was performed during the 9th week of pregnancy and the patient was maintained sub-o sequently on warfarin. One patient (PalaciosMacedo et al., 1969) received no anticoagulantso̊ throughout pregnancy with no complication. Details of the management of anticoagulant? therapy over the period immediately before and $>$ during delivery are insufficient in most reports to allow full analysis. In three patients the oral anti-N coagulant was stopped 4 to 12 weeks before the estimated date of delivery and injection of heparin was substituted. In two patients the orale anticoagulant was tailed off at this stage and no anticoagulant was given till term. The one patiento who died was maintained on subcutaneous heparin until the 28th week and on intravenous? heparin thereafter until Caesarean section in the 31 st week of pregnancy. In 11 patients oral anti-웅 coagulants were continued until the onset of labour or within one week of delivery. Four of these patients underwent premature labour ando delivered stillborn infants. 
Aortic valve replacement Ten patients had aortic valve replacement. There were no fetal deaths or complications in this group.

Maternal complications Systemic emboli occurred in two patients (Strickland and Mount, 1966 ; Hedstrand and Cullhed, 1968) between surgery and pregnancy but in neither during pregnancy. One patient reported by Hedstrand suffered cerebral and renal emboli in the 35th week when oral anticoagulants were withdrawn. Otterson et al. (1968) reported the occurrence of systemic emboli in the 14th week, two weeks after warfarin therapy had been stopped. There were no maternal deaths.

Anticoagulants Three patients (Starke et al., 1967 ; Strickland and Mount, 1966 ; Ueland et al., 1966) received no anticoagulants at any time after operation or during pregnancy. In a further patient (Ueland et al., 1966) warfarin was stopped as soon as pregnancy was diagnosed. The brief report by Zitnik et al. (1969) does not state whether anticoagulants were used. Five patients were given anticoagulants during pregnancy. One (Otterson et al., 1968) had warfarin till the 12th week and heparin from the 14th week till term. In another patient (Gordon and O'Loughlin, 1969) phenindione was given until the onset of labour and was then temporarily withheld. The remaining three patients reported by Hedstrand and Cullhed (1968) received dicoumarol. In one of these the dose was reduced at the 30th week and finally stopped at the 38th week. In another, dicoumarol was stopped at the 36th week and heparin was given thereafter. In the third patient dicoumarol was stopped at the 33rd week but systemic emboli occurred and therapy was reinstituted. The anticoagulant was eventually withheld one week before delivery and heparin was given.

COMBINED COMPLICATION RATES In both groups a total of 23 patients were on oral anticoagulants from conception and through the greater part of pregnancy. In this selected group there were seven fetal or infant deaths and two cases of congenital malformation. It must be pointed out that five of the deaths occurred in one series of six pregnancies; the remaining patient in this series, who delivered a live infant, was not anticoagulated.

Three patients out of the 28 had systemic emboli during pregnancy and one of these died with a valve immobilized by clot. Emboli followed cessation of anticoagulant therapy in two of these patients; no further emboli occurred after full anticoagulation was restored. The third patient was on intermittent subcutaneous heparin at the time emboli occurred.

One patient developed a vaginal haematoma and a second a haematoma at the episiotomy site on the fourth day. Both these patients received heparin during labour, but oral anticoagulant therapy had been resumed. In neither was anticoagulation excessive at the time the haematoma occurred. A further patient developed a haematoma in the incision for lower segment Caesarean section (see case 2 report).

\section{DISCUSSION}

Continuous full anticoagulation is usually indicated in patients with prosthetic heart valves because of the risk of thromboembolism (Starr, Herr, and Wood, 1967; Yeh, Anabtawi, Cornett, and Ellison, 1967; Akbarian, Austen, Yurchak, and Scannell, 1968). An increase in clotting factors in the blood (Pechet and Alexander, 1961) and depression of fibrinolysis (Bonnar et al., 1969) have been demonstrated in pregnancy which may increase the risk. However, the dangers to the fetus of oral anticoagulants given to the mother are not negligible (Gordon and Dean, 1955; Mahairas and Weingold, 1963 ; Villasanta, 1965) and if patients with valve prostheses become pregnant the physician must weigh the fetal risk of anticoagulation against the maternal risk of embolism if anticoagulants are withdrawn.

The published case reports suggest that the risk to the fetus is the major issue. The figures now available do not suggest that there is an increased risk of emboli from a prosthetic valve during pregnancy. Four patients who were never anticoagulated had successful pregnancies uncomplicated by embolisms. Five patients with a history of emboli before pregnancy did not suffer emboli during pregnancy. Three of the 28 pregnancies reported here were complicated by systemic emboli and in two of these routine anticoagulants had been stopped shortly before emboli occurred. In the third patient the embolic phenomenon may be related to the type of valve used. The danger of sudden cessation of anticoagulant therapy in this group of patients has been stressed by Akbarian et al. (1968).

Of the 23 cases reported in which oral anticoagulants were used, there were seven fetal or infant deaths and two abnormal infants. Villasanta (1965) and others (Gordon and Dean, 1955 ; Mahairas and Weingold, 1963) have reported a 
significant incidence of fetal deaths from oral anticoagulants given during pregnancy, but Aaro, Johnson, and Juergens (1967) and others (Bloomfield and Rubinstein, 1969; Finnerty and Mackay, 1962) suggest that the crucial factors are meticulous control of therapy and discontinuation of the drugs sufficiently long before labour to allow prothrombin times in both fetus and mother to return to normal. Of the seven fetal deaths the case of Bennett and Oakley (1968) can be excluded from consideration because the mother had sufficient systemic disease to vitiate the chances of the fetus ; in addition, the mother received heparin only during her pregnancy. In the case reported by Kenmure (1968) the mother was diabetic and the fetal death thus could not be attributed wholly to anticoagulant therapy. The remaining five deaths occurred in the series reported by Palacios-Macedo et al. (1969). In only two cases was evidence adduced that fetal death was related directly to anticoagulant therapy although the authors felt that 'the relation between this treatment and fetal death was very suggestive' in the remaining three cases. The authors imply that anticoagulation was excessive at times in their cases and, as discussed previously, this would increase the risk to the fetus. One fetal death in their series was associated with a thrombotest time increased to 334 seconds ( 200 seconds represents about $5 \%$ activity, approximately the limit for safe treatment).

The available evidence suggests, therefore, that properly controlled anticoagulant therapy, and in particular the avoidance of overtreatment, is not attended by an excessive fetal mortality. There remains the question whether fetal abnormality is caused by warfarin when used during the first trimester of pregnancy, as suggested by Kerber et al. (1968). The risk appears comparatively small. Two infants showed mental abnormality and malformed nasal bones out of the 23 reported cases in which oral anticoagulants were given in the first trimester. The part oral anticoagulants may have played in the causation of the stillbirths remains speculative.

The only alternative to the coumarin-indanediones, which cross the placenta (Quick, 1946), is heparin, which has a much higher molecular weight and does not enter the fetal circulation. Heparin could be given during the first three months but pregnancy would have to be diagnosed very early for useful gain and the disadvantages of long-term intermittent heparin have been stressed by Douglas (1962).

If it is decided to continue oral anticoagulants through pregnancy a further problem is their $\stackrel{\overrightarrow{\bar{s}}}{\overrightarrow{3}}$ management during labour. Hedstrand and Cull-O hed (1968) suggest stopping oral anticoagulants을 five days before delivery and continuing with $\frac{\bar{\rho}}{\vec{D}}$ heparin. These authors point out that the effect $\stackrel{\square}{\square}$ of heparin can be reversed rapidly with protamine sulphate. Gordon and O'Loughlin (1969) advise

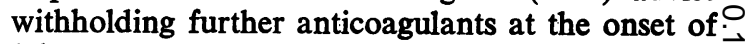
labour and stress the importance of restarting $\vec{\omega}$ anticoagulant therapy immediately after delivery. Bloomfield and Rubinstein (1969) and others $\overrightarrow{\vec{x}}$ (Aaro et al., 1967 ; Finnerty and Mackay, 1962) N suggest that fetal haemorrhage may be avoided by meticulous anticoagulant control during pregnancy, $\sim$ withdrawing treatment two to four weeks before labour. There is no evidence to elucidate whether응 it is the withdrawal of the drugs before labour or the previous avoidance of hypercoagulability which is the essential factor.

In seven of the published cases intermittent $\stackrel{\rho}{5}$ heparin treatment was substituted for oral anti- $\vec{\theta}$ coagulants two or more weeks before delivery.and, despite Douglas's (1962) strictures, no detectable embolism occurred. Oral anticoagulants were given as late as the onset of labour in 11 patients and in five of these excessive anticoagulation may be suspected. In one of the cases we report, fresh- $\bar{D}$ frozen plasma (Cosgriff, Cross, and Habif, $1948 ; \stackrel{\circ}{\rightleftharpoons}$ Ingram and Richardson, 1965) was used to reverse $\frac{O}{3}$ the anticoagulant effect rapidly and intravenous heparin was started. Neither in this case nor in any of the remaining five reported cases of the 11 kept on oral anticoagulants to term did fetal $\vec{\circ}$ haemorrhage occur. This is at least suggestive that careful anticoagulant therapy may be more im- $\cdot \frac{x}{0}$ portant in the prevention of fetal bleeding than 3 discontinuing the drug well before delivery.

We therefore suggest the following regime of $\frac{}{\xi}$ anticoagulant therapy during pregnancy, assuming 0 that facilities for adequate laboratory control are available :

(1) Continue oral anticoagulation throughout pregnancy.

(2) At the onset of labour the previous antico- $N$ agulation is rapidly reversed with fresh-frozen $N$ plasma, and intravenous heparin is substituted.

(3) Oral anticoagulation is started immediately after delivery but intravenous heparin is con- $\frac{C}{\Phi}$ tinued until this becomes effective. Particular care $\stackrel{\oplus}{+}$ must be taken in the control of dosage during 0 this period as the patient's sensitivity returns to the non-pregnant level.

(4) If the indication arises, fresh-frozen plasma $\stackrel{2}{\mathbb{Q}}$ may be given to the infant immediately after delivery. 
(5) Breast feeding should be avoided in these patients because oral anticoagulants are excreted in the milk.

Using this regime one of our patients successfully underwent Caesarean section, and anticoagulation was discontinued only for the brief period of the operation itself.

This scheme of management affords the mother the maximum possible protection from thrombo. embolism, and the risks to the fetus are held to a minimum by careful control of therapy. The risk of congenital malformation, as previously discussed, appears small.

Our grateful thanks are due to Professor T. Counihan, Dublin, and Dr. R. Daley and Professor P. Rhodes, St. Thomas' Hospital, London, for referring these cases and for advice during their management. Our thanks are also due to Dr. G. I. C. Ingram for helpful advice in the management of case 2 and in the preparation of this paper.

\section{REFERENCES}

Aaro, L. A., Johnson, T. R., and Juergens, J. L. (1967) Acute superficial venous thrombophlebitis associated with pregnancy. Amer. J. Obstet. Gynec., 97, 514.

Akbarian, M., Austen, W. G., Yurchak, P. M., and Scannell, J. G. (1968). Thromboembolic complications of prosthetic cardiac valves. Circulation, 37, 826.

Bennett, G. G., and Oakley, C. M. (1968). Pregnancy in a patient with a mitral-valve prosthesis. Lancet, 1, 616.

Bloomfield, D. K., and Rubinstein, L. I. (1969). Mitral-valve prosthesis, warfarin anticoagulation, and pregnancy. Lancet, 2, 290.

Bonnar, J., McNicol, G. P. and Douglas, A. S. (1969). Fibrinolytic enzyme system and pregnancy. Brit. med.J., 3, 387.

Carty, A. T., and Crowdes, R. L. (1968). Letter to Editor. Lancet, 2, 456.

Cosgriff, S. W., Cross, R. J., and Habif, D. V. (1948). Excessive hypoprothrombinemia due to 'dicumarol'; its treatment with lyophilized plasma. J. Amer. med. Ass., 138, 405.

DiSaia, P. J. (1966). Pregnancy and delivery of a patient with a Starr-Edwards mitral valve prosthesis. Obstet. Gynec., $28,469$.

Douglas, A. S. (1962). Anticoagulant Therapy. Blackwell, Oxford.

Finnerty, J. J., and Mackay, B. R. (1962). Antepartum thrombophlebitis and pulmonary embolism. Obstet. Gynec., 19, 405.

Gordon, G., and O'Loughlin, J. A. (1969). Successful pregnancies in two patients with a Starr-Edwards heart valve prosthesis. J. Obstet. Gynec., Brit. Cwlth, 76, 73.

Gordon, R. R., and Dean, T. (1955). Foetal deaths from antenatal anticoagulant therapy. Brit. med. J., 2, 719.
Harthorne, J. W., Buckley, M. J., Grover, J. W., and Austen, W. G. (1967). Valve replacement during pregnancy. Ann. intern. Med., 67, 1032.

Hedstrand, H., and Cullhed, I. (1968). Pregnancy in patients with prosthetic heart valves (Starr-Edwards). Scand. J. thorac. cardiovasc. Surg., 2, 196.

Ingram, G. I. C., and Richardson, J. (1965). In Anticoagulant Prophylaxis and Treatment, p. 179. Charles C. Thomas, Springfield, Illinois.

Johnson, A. S., Meyers, M. P., Eckhous, A. S., Bacher, B., and Limia, A. (1966). Successful pregnancies in patients with prosthetic mitral valves. Michigan Med., 65, 718.

Kenmure, A. C. F. (1968). Pregnancy in a patient with a prosthetic mitral valve. J. Obstet. Gynaec. Brit. Clwth, $75,581$.

Kerber, I. J., Warr, O. S., and Richardson, C. (1968). Pregnancy in a patient with a prosthetic mitral valve. J. Amer. med. Ass., 203, 223.

Mahairas, G. H., and Weingold, A. B. (1963). Fetal hazard with anticoagulant therapy. Amer. J. Obstet. Gynec., 85, 234.

Otterson, W. N., McGranahan, G., and Freeman, M. V. R. (1968). Successful pregnancy with McGovern aortic prosthesis and long-term heparin therapy. Obstet. Gynec., 31, 273.

Palacios-Macedo, X., Díaz-Devis, C., and Escudero, J. (1969). Fetal risk with the use of coumarin anticoagulant agents in pregnant patients with intracardiac ball valve prostheses. Amer. J. Cardiol., 24, 853.

Pechet, L., and Alexander, B. (1961). Increased clotting factors in pregnancy. New Engl. J. Med., 265, 1093.

Quick, A. J. (1946). Experimentally induced changes in the prothrombin level of the blood. III. Prothrombin concentration of new-born pups of a mother given dicumarol before parturition. J. biol. Chem., 164, 371 .

Starke, H., Dunn, M., and Kittle, C. F. (1967). Successful pregnancy following Starr-Edwards prosthetic aortic valve replacement. J. Kans. med. Soc., 68, 252.

Starr, A., Herr, R. H., and Wood, J. A. (1967). Mitral replacement: review of six years' experience. J. thorac. cardiovasc. Surg., 54, 333.

Strickland, N. R., and Mount, J. (1966). Pregnancy after treatment of aortic stenosis and insufficiency with a Starr-Edwards valve. Obstet. Gynec., 27, 508.

Turner, R. W. D., and Kitchin, A. H. (1968). Pregnancy after mitral-valve prosthesis. Lancet, 1, 862.

Ueland, K., Tatum, H. J., and Metcalfe, J. (1966). Pregnancy and prosthetic heart valves. Report of successful pregnancies in 2 patients with Starr-Edwards aortic valves. Obstet. Gynec., 27, 257-260.

Villasanta, U. (1965). Thromboembolic disease in pregnancy. Amer. J. Obstet. Gynec., 93, 142.

Yeh, T. J., Anabtawi, I. N., Cornett, V. E., and Ellison, R. G. (1967). Influence of rhythm and anticoagulation upon the incidence of embolization associated with StarrEdwards prostheses. Circulation, 35, Suppl. 1, p. 77.

Zitnik, R. S., Brandenburg, R. O., Sheldon, R., and Wallace, R. B. (1969). Pregnancy and open-heart surgery. Circulation, Suppl. I, 39, p. 257. 